International Journal of Social Sciences and Humanities
Available online at http://sciencescholar.us/journal/index.php/ijssh
Vol. 3 No. 3, December 2019, pages: $99 \sim 108$
e-ISSN: 2550-7001, p-ISSN: 2550-701X
https://doi.org/10.29332/ijssh.v3n3.356

\title{
Program Evaluation: Implementation of Tourism Village Development
}

\author{
I Gede Sudirtha $^{\text {a }}$, Ketut Widiartini ${ }^{\text {b }}$, Made Suriani ${ }^{\text {c }}$ \\ Article history: Received 18 April 2019, Accepted: 31 August 2019, Published: 22 November 2019
}

\section{Correspondence Author ${ }^{\text {a }}$}

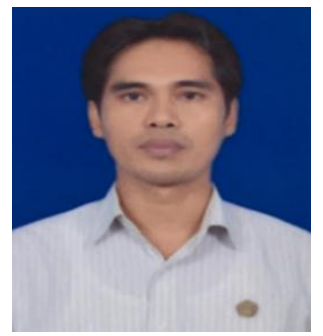

\section{Keywords}

based on local culture; development of rural; program evaluation; tourism products; tourism village;

\begin{abstract}
The tourism development program is a sustainable development program that has a vision of achieving equitable economic growth in the community that is based on the utilization of the potential of natural resources and other resources in the community. This study aims to examine the potential and problems in the development of tourism villages in Sambangan Village, Sukasada District as one of the Tourism Villages stipulated in Buleleng Regent Decree No. 430/405/HK/2017 concerning Tourism Village of Buleleng Regency. The research began with an evaluation study using the UCLA CSE model approach. The results showed aspects of the development of tourism villages in Sambangan Village have not yet maximally utilized natural resources or other resources as a viable tourism village product. From the results of the analysis conducted, the development of this tourism village product requires a management model that combines the elements of natural resources in the village with Balinese local wisdom that underlies the life and behavior of the Balinese people in general and requires a touch of technology-based innovation.
\end{abstract}

e-ISSN: 2550-7001, p-ISSN: 2550-701X ${ }^{\odot}$ Copyright 2019. The Author. SS Journals Published by Universidad Técnica de Manabí. This is an open-access article under the CC BY-SA 4.0 license (https://creativecommons.org/licenses/by-sa/4.0/) All rights reserved.

\section{Contents}

Abstract 99

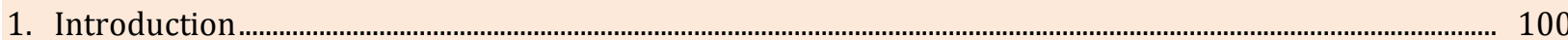

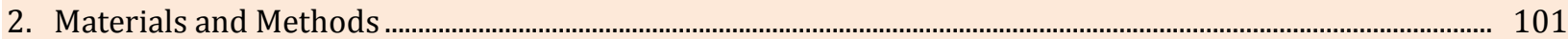

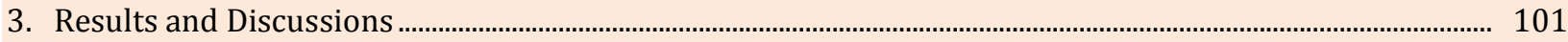

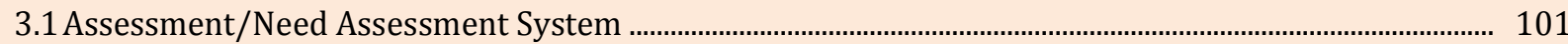

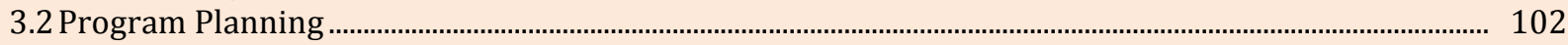

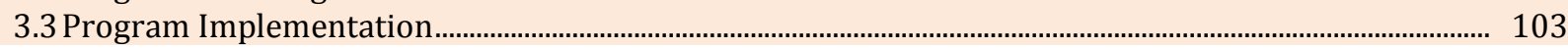

a Ganesha Education University, Singaraja, Indonesia

b Ganesha Education University, Singaraja, Indonesia

c Ganesha Education University, Singaraja, Indonesia 


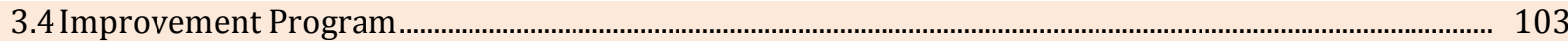

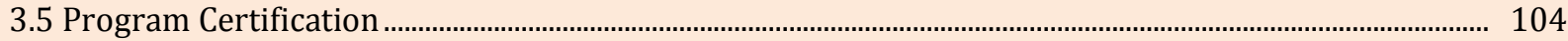

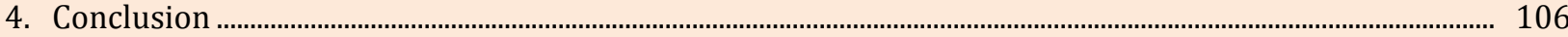

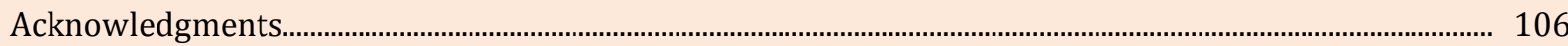

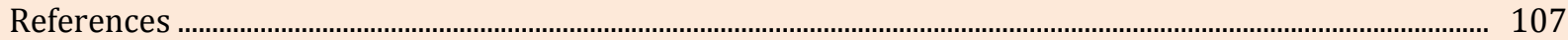

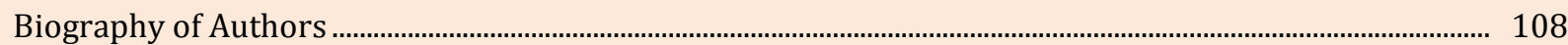

\section{Introduction}

Many recommendations written by researchers and observers in the field of tourism in Bali to develop Balinese tourism should be based on the values of local wisdom and rely on community strength by empowering local communities to create harmony in society. Pitana \& Diarta (2009), Development and development of tourist objects and attractions must be based on local wisdom and a local special sense that reflects the uniqueness of cultural heritage and the uniqueness of the environment. This local wisdom is a part of the culture of a society that cannot be separated from the language of the community itself. Ginaya et al., (2019), mention; tourism development is not only concentrated with commodity-based development of products of economic value so that it has added value, but must also be based on the values of local wisdom to create harmony in people's lives, so that there is no interesting struggle conflict between stakeholders and people who are tourism actors, Arsa \& Widiastini (2018), explained the development of rural tourism is expected to be sustainable in environmental, social and economic aspects. Referring to Perda number 2 of 2012 concerning Bali tourism destinations, it is further explained that community involvement, especially in socio-cultural activities, must be present in the development of tourism in Bali. Community-Based Tourism which is often carried out by tourism actors in developing tourism in Bali should be in accordance with the ideas, ideals, vision, and mission of the development of community-based tourism. But the ideas that are being discussed still need to be revealed and implemented by designing certain models that are able to make Bali tourism as expected.

In the midst of developing a discourse on the development of community-based tourism villages, Bali's tourism potential from year to year seems to be shifting along with the decreasing of paddy fields and other resources that have changed functions uncontrollably. Sedana \& Astawa (2019), said that the very limited area of Bali will diminish if land-use change, especially agricultural land, cannot be dammed. This is experienced by Bali today. The implementation of policies that sometimes do not favor local communities is also an obstacle to the development of local community-based tourism. Usually, the development of tourism is more in favor of the owners of capital (capitalists) who easily change nature into something they want without looking at the interests of society socially, culturally, and economically sustainable for local communities.

Basically, the aim of tourism development is to build better economic growth as expressed by Naser Egbali et al., (2010). The most important objective of tourism development is the economic and social development of the tourism area. Even though a small part of tourism includes rural tourism and plays an important role in the economies of rural areas in developed countries, other benefits and even receiving danger through these activities in rural areas should not be ignored. Because some benefits can be obtained from tourism development, improper development will bring harm and negative effects. However, the level of this effect will be changed proportionally with different factors such as the importance of the local tourism industry, the potential of tourists and their activities, the consolidation of the local environment and local cultural and cultural authorities.

Furthermore, the research results of Ginaya et al., (2019), identified that mass and massive tourism can make Bali lose its Balian identity. Bali does have its own characteristics, and Balinese culture has remained stable until now. In addition to culture, many other factors are also the attraction (taksu) of the island of Bali, such as natural beauty which is described as "heaven on earth". It is understandable if Bali finally has the largest tourism asset in Indonesia. In addition, it is difficult to deny that religious rituals in Bali, which are usually called yadnya at any time, are so unique that tourists are not bored to enjoy even to capture them with their photos or videos. But the development of tourism has led to the proliferation of pragmatic lifestyles among people to sell their land for short-term interests. This happens also because the government policy in 
the field of taxation with the policy of adjusting the tax object in which each tourist area has a strategic value so that land and building taxes are high.

From several phenomena and discourses in the development of tourism villages, this evaluative study was carried out to obtain an overview of the management of tourism villages in Desa Sambangan and is expected to produce a study of the real conditions of rural tourism development, as well as to conduct various comparative studies in several villages and study several articles related to the development of tourist villages in several areas, as well as assessing some of the potentials owned by villages such as natural resources and other resources.

\section{Materials and Methods}

This research was conducted through an evaluative study using the CSE-UCLA approach to the development of tourism objects and attractions in Sambangan Village through the BUMDES program. The CSE-UCLA evaluation model developed by Alkin has five evaluation phases: the assessment system, program planning, program implementation, program improvement, and program certification (Wisudawati \& Maheswari, 2018). Furthermore, Divayana (2017), states that the program evaluation model using the CSE-UCLA approach evaluates the program in five stages of evaluation, namely: assessment system, program planning, program implementation, program improvement, and program certification. Data collection methods are carried out through observation, interviews, and document studies on village officials, BUMDES, tour operators, guides, the community, and tourists who are visiting. Data were analyzed using qualitative descriptive methods with steps: data reduction, data presentation, interpreting data, and drawing conclusions. In accordance with the design of the study after going through 5 evaluation indicators, a general picture of the effectiveness of the ongoing tourism development program in Sambangan Village, Sukasada District, Buleleng Regency, Bali, was obtained based on the Decree of the Regent of Buleleng No. 430/927 / HK / 2015. This picture of effectiveness has led to recommendations for the development of a new tourism village model.

\section{Results and Discussions}

This study was conducted in-depth evaluative studies of several aspects that exist in various objects and tourist attractions in the Village of Sambangan. The appropriate approach in this evaluative study is to use the CSE approach UCLA (Center for the Study of Evaluation-University of California in Los Angeles) which is able to explore various problems and potential possessed by the object. Evaluative studies are conducted using indepth interviews, and direct observation in several aspects of evaluation and analysis of evaluation indicators consisting of system assessment, program planning, program implementation, program improvement, and program certification)

\subsection{Assessment/Need Assessment System}

The Sambangan tourism village development program does not yet have a clear, written vision, mission, and goals in each village tourism development program, from the interviews it provides different answers about the vision and mission formulation starting from the village head, the head of the Village Owned Enterprise, and managers of tourism-aware groups, as well as village community leaders. This was also asked by several members of the public and tourism actors around the tourist attraction stating that they did not know about the vision, mission, and destination of the tourism village. However, the formulation of the vision and mission presented shows almost the same direction and purpose identified from several keywords that appear around: improving the community's economy, economic equality, involvement of local communities, conservation of natural resources (waterfalls and state forests as icons of the village of Sambangan), and nature conservation. The needs of local tourism farmers who know the background of the village and the potential of village tourism and who are able to provide the correct explanation with several languages are still constrained. Mainly using foreign languages (English). Existing support from the Sambangan Village tourism development program has been very good as in the community groups that are not incorporated in

Sudirtha, I. G., Widiartini, K., \& Suriani, M. (2019). Program evaluation: implementation of tourism village development. International Journal of Social Sciences and Humanities, 3(3), 99-108. https://doi.org/10.29332/ijssh.v3n3.356 
tourism groups, are aware and willing to contribute in realizing Sapta Enchantment (security, order, cleanliness, coolness, beauty, hospitality, and memories), as pecalang (village security guard), parking attendant, and several other forms of support in the provision of accommodation facilities for food stalls and small restaurants, as well as some support from entrepreneurs outside the village who invest their funds in the interests of providing accommodation and management of some village objects. On the other hand, with the issuance of the Decree of the Regent of Buleleng No. 430/927 / HK / 2015, he gave enthusiasm and quite high efforts to the village to carry out the development of the Sambangan Tourism Village.

\subsection{Program Planning}

In this second stage, an evaluation is carried out to obtain data directly related to meeting the needs identified in the first stage, which is related to planning. In this case, the developed programs are carefully evaluated to find out whether the plan has been prepared based on the results of the needs analysis. Evaluation of this stage cannot be separated from the objectives that have been formulated. Thus the analysis is focused on: 1) Analysis of the potential and support in the selection of object development programs. Sambangan village has a tourism potential that originates from natural resources in the form of a very abundant tang water source in the middle of the village forest which is a border area with Desa Wanagiri and Desa Ambengan in Kecamatan Sukasada. The existence of seven (7) waterfalls is very much realized by the community and the village will still exist if the existence and function of the forest are maintained. This potential is utilized by the village as a center and icon for developing tourist destinations that need to be managed well. Other natural resources are also in the form of landscapes in the form of a very wide rice field area stretching very beautifully with a terracing system that is managed based on the subak system. However, according to the data obtained there has been a significant change or change in the function of paddy fields from 2012 data of $214 \mathrm{Ha}$ to $201 \mathrm{Ha}$ until 2017 (source: Sukasada Subdistrict in figures). This change was also expressed by Tomy Ahmadi et al., (2016), the area of rice fields in the past five years has decreased which is nothing but due to the conversion of land to non-agriculture. Factors influencing the change of land use in Sambangan Village are the appearance of urban sprawl that will cause suburbs to experience changes in land use so that land demand will increase while agricultural businesses are considered to be less profitable because it is highly dependent on nature when compared to other sectors such as shops or housing business activities. 2) The organizational structure in managing this potential is within the structure of the Village Owned Enterprises (BUMBES) of Sambangan Village which has existed since 2017. 3) the development of a sustainable Tourism Village with a nature conservation perspective into a grand design program, while 4) programs and activities designed in the form of providing a place of visit that is more in accordance with the wishes or needs of guests as a new alternative in providing attraction under the coordination of groups travel aware. 5) seen from the readiness and capability of the management of the tourism village under the BUMDES which still very much needs to improve in the fields of management, human resource development, and the development of destination forms that have a unique appeal and continue to be based on regional potential. For this reason, the development of Sambangan Village as a tourism village really needs assistance from various parties, as has been done by several academics from several universities in Bali related to the management of tourism village management, financial management, tourism human resources. 6) readiness of the government / customary village and 7) readiness of the local community. Government readiness through village government offices and customary villages including community readiness shows increasingly readiness, especially the village government already has an official permit in the form of a Decree of the Regent of Buleleng No. 430/927/ $\mathrm{HK} / 2015$, and a number of assistance from the local government that makes the village of Sambangan as one of the tourist villages. Judging from the number of tourist visits per month based on the results of the survey in the reception of tourist visits, the number of visits reached 300 people per day. The number of visits shows that this tourism village physically has enough readiness to accept tourist visits. The number to date is expected to continue to grow so that more readiness is needed from both villages and villagers to receive positive and negative effects from tourism. For this reason, some management guidance and improvement are needed from each side of management and implementation of tourism that is of an international standard and is certainly capable of synergizing and integrating local genius values as a pillar of tourism support as it is seen as a tourist village with an insightful and sustainable local community by preserving sustainability, natural resources, environment, and local culture. 


\subsection{Program Implementation}

In the program implementation indicator, the evaluation focuses on the following matters: 1) the socialization of the vision and mission of the program objectives to all components of the community and stakeholders is done through the office of the village head, BPD, LPM, kelian banjar/dusun, and kelian subak. The results of interviews with several components of the village and villagers, the existence of programs and activities related to rural tourism, have been directly and indirectly communicated and disseminated through meetings and talks in the village. Besides through village meetings and paruman traditional villages, the community consciously sought information related to the existence of activities and programs. This is evident from a number of activities programmed in the village which are strongly supported by the community through its actions, such as the realization of enchantments that involve all levels of society. 2) several forms of programs / activities that are designed and implemented in the form of: construction of tourist huts, hydroponic parks, arrangement of waterfalls, and some selfies for tourists, and efforts to open access paths by tourism conscious groups to waterfalls that are difficult to reach, tourism designs camps, and accommodation designs using residential houses or villa developments in the form of joglo houses, and glebegs, and the arrangement of places that allow for more extreme tourist activities such as jumping around rivers and waterfalls. 3) Associated with these activities indirectly the information has reached the community through word of mouth so that the introduction of program introduction to the community is not constrained. 4) likewise the introduction of program socialization to the community outside the village was gradually conveyed, and even faster all forms of tourism activities in the village of Sambangan had reached the international level through internet-based social media, and even until there was a Hollywood film director shooting a film in one of the waterfalls in Sambangan Village, and 5) thus the socialization of the introduction of programs, places, and activities of tourists has been socialized to all stakeholders directly or indirectly through various media, but the fastest and broader form of socialization is through social media like Instagram and Facebook.

In socializing the existence and implementation of activities/programs, it was found to have been implemented quite well (up to the lowest strata of society, namely by being able to utilize and employ 50 villagers who were once unemployed to become village tourism workers and an increase in local income to Sambangan village. However also found obstacles related to the existence of programs or activities that intersect socially and economically with neighboring villages, especially related to the management of borders that have mutual interests. This has not been able to be properly addressed by village communities, if not managed properly someday will cause conflicts between villages that border, things like this need to be managed well by the Sambangan tourism village management component.

\subsection{Improvement Program}

The evaluation indicators on the improvement program are directed at the focus of questions about 1) the benefits of the program for the local community, 2) the benefits for the district / customary village government, 3) the benefits for the stakeholders, 4) the object management operations, 5) the general community response, 6) response to visitor satisfaction, 7) reflection on the implementation and response of visitor satisfaction. In general, this village tourism program is very beneficial and has a benefit called the multi-layer effect for the community as well as village and regional governments. For the local government this program is said to help the government program in order to increase tourist visits to the Regency of Buleleng, which has been very lame between North and South Bali, this program is also able to increase public awareness related to environmental preservation, nature, and better know and implement sapta enchantment (security, order, cleanliness, coolness, beauty, hospitality, and memories), this program also contributes to the interest of community groups and the wider community directly related to the growth of several economic activities, such as the development of stalls, restaurants, lodging, villas, both managed by the local community and some outside investors. The response of visitors or tourists is very good seen by visitor satisfaction and the increasing number of visitors significantly. As well as getting 4 to 5 -star awards. As well as several reviews obtained from the impression of tourists submitted through social media said 90\% gave a very positive impression and said they would convey their good experiences to their colleagues in their respective

Sudirtha, I. G., Widiartini, K., \& Suriani, M. (2019). Program evaluation: implementation of tourism village development. International Journal of Social Sciences and Humanities, 3(3), 99-108. https://doi.org/10.29332/ijssh.v3n3.356 
countries. In 2017 the village of Sambangan won the silver category in a tourism communication forum in Bali.

\subsection{Program Certification}

The final indicator of the evaluation of this program is directed to the program certification seen from the side: 1) physical appearance of the object. Waterfall as a form or physical appearance of the object that became the most famous icon in Sambangan Village. There are 7 (seven) waterfalls in the village of Sambangan namely: Aling-Aling waterfall, Kroya waterfall, Cemara, Dedari, Kembar, canging, and shoots. Of all the waterfalls available, there are two well-known waterfalls namely aling-aling waterfall and crocodile waterfall. Both of these waterfalls have a physical appearance that has a good appeal and allows tourists to do sliding and jumping activities. While the other waterfalls still do not have greater appeal compared to the two well-known waterfalls, besides access to the road leading to the water waterfalls need to be thought about to be more affordable. In addition to the waterfall, Sambangan Village also has a landscape of paddy fields that has a good appeal but needs to be managed and made an attraction that allows tourists to enjoy. This is also an alternative destination that needs to be designed (the results of interviews with foreign tourists, they are also more interested in community activities that blend with local culture and customs, such as activities in the fields, religious ceremonial activities, and other cultures that need to be packaged well, foreign tourists also convey that they need food that allows them to carry it lightly when they travel around Sambangan attractions 2) the ability and potential attraction of objects for sale. All the potential tourist attractions in the village of Sambangan have good selling power and attractiveness, but all that needs management and packaging techniques, as well as opening access paths to tourist attractions that are comfortable, safe, and affordable, although so far the visitors have felt and made a comfortable, happy impression, and most of them said they would recommend this place to the colleagues in their respective countries. 3) the safety and comfort of the visitors felt very good with the involvement of security elements from villages using pecalang traditional clothing, as well as the hospitality of the local guides, even though they still have limited language and information about the village which is still not the same and standard. 4) tourism carrying capacity in terms of: (1) Attraction (attraction) with the appearance of objects that are still very natural in the form of 7 waterfalls, forests, natural and beautiful panoramas, making all tourist attractions become very attractive for visitors to do tourist activities, even there are some suggestions from visitors who recommending the existence of activities or local cultural attractions that are held and are naturally and ongoing in the community are also displayed as attractions that need to be socialized to visitors. (2) Accessibility (accessibility). To go to tourist attractions in the Village of Sambangan still possible and affordable by visitors both domestic and foreign using private vehicles and transportation services provided by tourism services. From observations and interviews with guides and drivers who were taking visitors to the Sambangan Village location, some of the visitors took advantage of the transportation services from the hotel where they were staying. Most of them know the existence of the tourist village location from social media and publications via the internet. (3) Amenities (facilities). Tourists who visit Desa Sambangan are visitors who do not live directly in the Village location. They are visitors who come to Bali and stay elsewhere. So their visit is in the form of a short visit. Until now in terms of facilities are still very eligible. In terms of facilities such as accommodations needed by tourists such as hotels and restaurants, they can still fulfill what tourists want while they are in Sambangan. (4) Ancillary (institutional). The tourism management agency is managed by the government and the community of Sambangan Village, which is coordinated by the Village Owned Enterprises, as well as tourism awareness groups in the village. As a manager, this organization directly accommodates the interests and management of traditional tourism villages and emphasizes the involvement of local communities. With management like this, visitors feel comfortable, and safe while in tourist sites.

From all evaluation components used as evaluation materials for the implementation of the tourism village development program, several problems and recommendations have been obtained that stem from the absence of clear guidelines for managing a sustainable tourism village. Many of the potential natural resources of the village of Sambangan are not yet utilized for tourism purposes, but among many potential natural resources have been touched by the community disproportionately and have the potential to destroy nature because of the lack of intellectual capacity of the community to use the values of local wisdom as a guide. If this is allowed to have an impact on the development of tourism that is not in accordance with the spirit of the 
development of tourism in Bali that is based on culture, and natural resources that are maintained, and tourism that involves local communities. Therefore the development of tourism based on local wisdom values really needs to be studied and implemented more operationally. Bali's local wisdom is Sumada (2017), explains, Bali has a uniqueness that is formed in the noble values that were realized long before Indonesia's independence. The potential elements of Balinese culture (local genius) have proven their ability to survive until now. In accordance with the opinion of Suniastha Amerta (2017), local genius is able to withstand external culture, has the ability to accommodate elements of outside culture, has the ability to integrate external cultural elements into native culture, and has the ability to control, and able to give direction to cultural development. Furthermore, continued Sumada (2017), (120) explained, local wisdom (adat) is understood as everything that is based on knowledge and is recognized by reason and is considered good by religious provisions. However, a lack of understanding of local wisdom can cause disputes that end in a long crisis. This was also revealed from the results of a study by Supriyatama \& Wesnawa (2019), that one of the values of local wisdom was similar. By prioritizing the concept of addressing some social, economic, political problems in society it can be handled well the results of in-depth observations and interviews in Sambangan Village also have problems managing border areas with Ambengan villages that have the potential for conflict, including the management of forests in two areas, namely Sambangan Village and Wanagiri Village, which until now have not been resolved properly. From the concept of menyamabraya in this study, it is possible to overcome the problem of border areas in the context of tourism village management. This concept is based on the view that nyamabraya or close relatives have close social relations there is a view that life in the community cannot be separated from the surrounding community, which considers the surrounding community as siblings, so that life must be prosperous, both in social work and social sociology always prioritizing the community.

The social order in Balinese society must be strengthened and not be swayed by the inclusion of a new order which actually weakens the order that has been inherited since ancient times by the Balinese people. In general, local wisdom (local wisdom) can be understood as local ideas that are wise, full of wisdom, of good value, embedded and followed by members of the community. Tri Hita Karana, sad kertih, the concept of matching braya, the concept of mountain nyegara, hulu teben, tat twam asi, etc. Are all the concepts that underlie the Balinese life order purely used as a foundation. Astawa et al., (2019), examines some facts about the existence of local wisdom values that should be implemented in local management/management with extraordinary values such as the values: (1) Tri Hita Karana to maintain the safety of Bali's nature in situations of increasingly human needs increasing and diverse, (2) Working patterns of Balinese farmers, such as intercropping and the like which are also based and applied on the basis of pageh, puguh lan jengah, (3) Managing nature with a managerial approach based on sustainability or sustainable development, so that it is effective and effective for an unlimited period of time in line with a lifestyle orientation in the Balinese tradition called "loud cenik", (4) the system of trading in the trading model with the system of availability of all the needs of the buyer, (5) ngadas and nandu as a synergy between investors and workers, (6) Cingkreman as a model of capital fertilization, and others. Local values that exist in the Balinese community life structure need to be reconstructed to strengthen the existence of Bali, including in the model of tourism village management so that it is not eroded by foreign culture in the development of global tourism.

As has happened in Sambangan village, at least there has been a quite drastic change in land use seen in Sambangan Village. Ahmadi et al., (2017), in their analysis of changes in land use in Sambangan Village in the period 2101 to 2017 there are differences in the landscape with its breadth. The area of paddy fields in 2012 was 214 hectares and the fields were 202 hectares. In 2017, the area of paddy fields will be $201 \mathrm{Ha}$ (reduced by $23 \mathrm{Ha}$ ) and moor to $197 \mathrm{Ha}$ (reduced by $5 \mathrm{Ha}$ ). Settlements in 2012 amounted to $126 \mathrm{Ha}$ to $144 \mathrm{Ha}$ in 2017. While the area of state forest that did not have a permanent change of function was $40 \mathrm{Ha}$, but based on interviews with several village officials and some residents around the forest it was seen that there were sufficient forest exploitation and exploitation efforts such as logging and some are used as community-owned gardens (in the middle of the forest). There are also a number of water sources around the forest that function as micro hydropower plants that are managed privately, so some waterfalls that run out of the water and some large trees that support the forest also die.

Community empowerment is also an important thing to do, where the community is not only a passive participant but also as an active participant who is able to independently empower after tourism is developed in the area. In carrying out social, economic, religious, and political life, the Balinese are guided by teachings

Sudirtha, I. G., Widiartini, K., \& Suriani, M. (2019). Program evaluation: implementation of tourism village development. International Journal of Social Sciences and Humanities, 3(3), 99-108. https://doi.org/10.29332/ijssh.v3n3.356 
originating from Hinduism. Then grow a soul that is very harmony from the community in running life. Tri Hita Karana's very famous values contain a philosophy of harmony between spirituality, humanity and the environment that unites and collaborates in the lives of Balinese people. Bali is very maintaining good relations between fellow human beings giving birth to the concept of God through offering to God (Hyang Widhi) for Balinese people who are very unique and different from the majority of people who are outside Bali. Bali is very famous for its ritual spirit. Bali has a variety of religious rituals that originally originated from the teachings of his religion (Vedas) and then unite and collaborate with the local culture where they are, Balinese people are able to change the things he gets from nature as a result of his efforts to work to exploit nature (such as farming, gardening, raising), etc., in the context of offerings (gratitude to the creator) developed into various kinds of rituals. The Balinese ritual spirit is a kind of spiritual concept that collaborates ideals, tastes, and intention into a culture. A culture that is able to change something natural into cultural in the concept of offerings and gratitude for all the gifts of God. This is what underlies the lives of Balinese people who do not exist in other areas. As one of the tourism development models, Ginaya, et al., (2019), also recommends a community-based tourism model (CBT) which states that the CBT model is a sustainable alternative tourism development, which prioritizes community participation in development and its operation. The soul and philosophical values of the Balinese people are the basis of Balinese life, no less important in the development of Balinese tourism, especially in the development of a tourist village.

\section{Conclusion}

Based on the results of the research and discussion described above, the following conclusions are obtained. An evaluation study of the Sambangan tourism village development program using the CSE-UCLA evaluation model approach, is able to provide a number of new recommendations for community-based tourism village management and local Balinese wisdom as a form of management that originates from the reconstruction of local values that have long existed and developed in a society that has been proven as a value that underlies social, political, economic life that makes society more harmonious and prosperous. These management recommendations will make tourism village management more optimal and make the village tourism program sustainable, so that it can help the process of developing tourism villages from components or elements of tourism that have better value in terms of (1) Attraction (strong attraction), (2) Accessibility (convenient and affordable accessibility), (3) Amenities (adequate facilities), (4) Ancillary (strong institutions based on local wisdom values), and upholding the basic concepts of sapta charm (security, order, cleanliness, coolness, beauty, hospitality, and memories). The quality of the implementation of the development of the Sambangan tourism village in terms of the CSE-UCLA evaluation model as a whole has proceeded with, but it requires assistance from various parties to make this tourism village a community-based sustainable program that integrates the value of local wisdom.

\section{Acknowledgments}

The authors would like to thank the reviewer for their consideration of the further process of the present paper. Thanks to the editor of IJSSH for the valuable support, time as well as advice. 
References

Ahmadi, H. B., Kusi-Sarpong, S., \& Rezaei, J. (2017). Assessing the social sustainability of supply chains using Best Worst Method.Resources, Conservation and Recycling, 126, 99-106. https://doi.org/10.1016/j.resconrec.2017.07.020

Ahmadi, T., \& Citra, I. P. A. (2016). Analisis perubahan penggunaan lahan desa sambangan, kecamatan sukasada, kabupaten buleleng. Jurnal Pendidikan Geografi Undiksha, 4(3).

Arsa, I. K. S., \& Widiastini, N. M. A. (2018). Jewelry in celuk: its trends, development, and implications for the village artisans. International Journal of Applied Sciences in Tourism and Events, 2(1), 70. http://dx.doi.org/10.31940/ijaste.v2i1.904

Astawa, I. K., Suardani, M., \& Suardani, A. A. P. (2019). Kuta beach area, bali: a study on tourism zoning and carrying capacity. International Journal of Applied Sciences in Tourism and Events, 3(1), 81-92. http://dx.doi.org/10.31940/ijaste.v3i1.1236

Divayana, D. G. H. (2017). Utilization of cse-ucla model in evaluating of digital library program based on expert system at universitas teknologi indonesia: A model for evaluating of information technology-based education services. Journal of Theoretical \& Applied Information Technology, 95(15).

Egbali, N. A. S. E. R., Nosrat, A. B., \& Pour, S. K. S. A. (2010). Investigation challenges and guidelines development of rural tourism-A case study of Rural Semnan Province. South Asian Journal of Tourism and Heritage, 3(2), 61-75.

Ginaya, G., Sudarmini, N. M., \& Damayanti, I. K. W. (2019). Tri hita karana and sad kertih values in Belimbing rural tourism development. International journal of social sciences and humanities, 3(2), 10-23. https://doi.org/10.29332/ijssh.v3n2.282

Made Sumada, I. (2017). Peranan kearifan lokal Bali dalam perspektif kebijakan publik. JIPSI-Jurnal Ilmu Politik dan Komunikasi UNIKOM, 7.

Pitana, I. (2009). Gde dan I Ketut Surya Diarta. Pengatar Ilmu Pariwisat, Penerbit Andi, Jakarta.

Poespowardoyo, S. dalam Ayatrohaedi, 1986. Kepribadian Budaya Bangsa: Local Genius, Pustaka Jaya, Jakarta.

Sedana, G., \& Astawa, N. D. (2019). Establishment of inclusive business on coffee production in Bali province: lesson from the coffee development project in Nusa Tenggara Timur province, Indonesia. Asian Journal of Agriculture and rural 111-122. http://dx.doi.org/10.18488/journal.1005/2019.9.1/1005.1.111.122

Suniastha Amerta, I. M. (2017). The role of tourism stakeholders at Jasri tourism village development, Karangasem regency. International Journal of Social Sciences and Humanities, 1(2), 20-28. https://doi.org/10.29332/ijssh.v1n2.32

Supriyatama, P. E., \& Wesnawa, I. G. A. (2019). Pemetaan distribusi objek wisata dan potensi wisata di kecamatan sukawati. Jurnal Pendidikan Geografi Undiksha, 7(1).

Surat Keputusan Bupati Buleleng Nomor 430/927/HK/2015 Tentang penetapan desa wisata Kabupaten Buleleng Tahun 2015

Undang-undang Republik Indonesia Nomor 9 Tahun 2010 Tentang Kepariwisataan.

Wisudawati, N. N. S., \& Maheswari, A. I. A. (2018). Potential of Silver Craft Product through to CommunityBased for Tourism Sustainability in Celuk Village. International Research Journal of Management, IT and Social Sciences, 5(1), 9-15. Retrieved from https://sloap.org/journals/index.php/irjmis/article/view/25

Sudirtha, I. G., Widiartini, K., \& Suriani, M. (2019). Program evaluation: implementation of tourism village development. International Journal of Social Sciences and Humanities, 3(3), 99-108. https://doi.org/10.29332/ijssh.v3n3.356 


\section{Biography of Authors}

\begin{tabular}{|c|c|}
\hline 9 & $\begin{array}{l}\text { I Gede Sudirtha is a Lecturer at the Ganesha University of Education, Bali- } \\
\text { Indonesia. He was born in Desa Buduk, Badung Regency on June 16th 1971. He } \\
\text { graduated his primary school in Desa Buduk (1981), a junior high school in Desa } \\
\text { Buduk (1987), Senior High School in Badung (1990) S-1 in Singaraja (1995), S-2 in } \\
\text { Yogyakarta State University (2002), and S-3 at Jakarta State University (2016). He } \\
\text { lived at Jalan Laksamana Barat, BTN Grya Permai, Desa Baktiseraga Singaraja- } \\
\text { Bali, Ph. 0818564033, } \\
\text { Email: gede.sudirtha@undiksha.ac.id }\end{array}$ \\
\hline & $\begin{array}{l}\text { Ni Ketut Widiartini is a lecturer at the Ganesha University of Education, Bali- } \\
\text { Indonesia. She was born in Singaraja, Buleleng Regency on August 1th 1975. She } \\
\text { graduated his primary school in Singaraja (1986), a junior high school in Singaraja } \\
\text { (1991), Senior High School in Singaraja (1993), S-1 in STKIP Singaraja (1997), S-2 } \\
\text { in Undiksha Singaraja (2006), and S-3 at Jakarta State University (2013). She lived } \\
\text { at Arteri Wixco Street, Banyualit Hamlet, Kalibukbuk Village, Singaraja-Bali, Ph. } \\
\text { 087876214063, } \\
\text { Email: ketut.widiartini@undiksha.ac.id }\end{array}$ \\
\hline & $\begin{array}{l}\text { Ni Made Suriani, S.Pd., M.Par. is a lecturer at Ganesha University of Education, Bali- } \\
\text { Indonesia. She was born on December } 7^{\text {th }} 1972 \text { in Sepang, Buleleng. She finished } \\
\text { her bachelor degree, majoring in Culinary Program of STKIP Singaraja (1997). } \\
\text { Then she continued to get Magister of Tourism in Udayana University (2009). She } \\
\text { lives in Sahadewa Street 21A Singaraja, Buleleng, Bali. } \\
\text { Ph +6287741649496 } \\
\text { Email : nimadesurianiandahani@gmail.com }\end{array}$ \\
\hline
\end{tabular}

